\title{
PENGARUH KEPRIBADIAN GURU BIOLOGI TERHADAP MOTIVASI BELAJAR PESERTA DIDIK DI SMP N 3 MATTIROSOMPE
}

\author{
Isrul \\ SMPN 3 Mattirosompe, Kabupaten Pinrang Sulawesi Selatan \\ E-mail: isrululfha@gmail.com
}

\begin{abstract}
Abstrak: Secara umum peserta didik akan termotivasi untuk belajar apabila ia melihat situasi pengajaran cenderung memuaskan dirinya sesuai dengan kebutuhannya. Jenis penelitian yang digunakan adalah deskriptif dengan pendekatan kuantitatif. Variabel bebas adalah pengaruh kepribadian guru biologi, dengan indikator: cara berbuat, sikap, minat, dan temperamen emosional. Variabel terikat adalah motivasi belajar peserta didik, dengan indikator: perasaan senang belajar, semangat belajar, dan niat yang kuat untuk belajar. Hasil Penelitian menunjukkan bahwa terdapat pengaruh kepribadian guru biologi terhadap motivasi belajar peserta didik di SMP Negeri 3 Mattirosompe. Besar pengaruh kepribadian guru biologi terhadap motivasi belajar peserta didik di SMP Negeri 3 Mattirosompe adalah $23 \%$.
\end{abstract}

Kata Kunci: motivasi belajar, kepribadian guru

\section{THE INFLUENCE OF THE PERSONALITY OF TEACHERS BIOLOGY AGAINST THE MOTIVATION TO STUDY SCHOOL TUITION AT JUNIOR SECONDARY SCHOOLS 3 MATTIROSOMPE}

\begin{abstract}
In general the students will be motivated to learn when he sees the situation teaching tend to satisfy his suit its needs. The kind of research use is descriptive with the quantitative approach. Variables reaches as high as free is the influence of the personality of teachers of biology, with an indicator: the manner of deliberately and knowingly practice committing, the measures and the behaviour, the lack of interest in, and temperament emotional. Variables reaches as high as bound is the motivation to study school tuition, with an indicator: a feeling of the joy of learning, eager to study, and the intention of well known fact that you to learn. The results of the study indicate that there has the influence of the personality of teachers biology against the motivation to study school tuition in the public junior high schools 3 Mattirosompe. Big the influence of the personality of teachers biology against the motivation to study school tuition in the public junior high schools 3 Mattirosompe is $23 \%$
\end{abstract}

\section{Keywords: The Motivation To Study, Personality Teachers}

Pendidikan adalah proses dalam rangka mempengaruhi peserta didik agar dapat menyesuaikan diri sebaik mungkin terhadap lingkungannya dan dengan demikian akan menimbulkan perubahan dalam dirinya yang memungkinkannya untuk berfungsi secara edukatif dalam kehidupan masyarakat ini agar sasaran dari perubahan itu dapat tercapai 
sebaik yang diinginkan (Depag, 2002). Pendidikan Indonesia yang berasaskan pendidikan seumur hidup menuntut agar semua materi pelajaran harus diprogramkan secara sistematis dan terencana dalam setiap jenis dan jenjang pendidikan. Dasar pendidikan seumur hidup tersebut sesuai dengan konsep dasar pendidikan nasional sebagaimana tercantum dalam Undang-undang Sistem Pendidikan Nasional Nomor 20 Tahun 2003 yang menyatakan bahwa pendidikan nasional adalah pendidikan yang berdasarkan Pancasila dan Undang-undang Dasar Negara Republik Indonesia Tahun 1945 yang berakar pada nilai-nilai agama, kebudayaan nasional Indonesia dan tanggap terhadap tuntutan perubahan zaman. Jadi, jelas bahwa pendidikan nasional lebih berorientasi untuk mengembangkan keewarganegaraan serta memelihara dan mengembangkan budaya bangsa. Fungsi pendidikan ini harus betul-betul diperhatikan dalam rangka perencanaan tujuan pendidikan nasional (Syaiful. B. D, 1997).

Pendidikan sekarang ini dituntut untuk mengikuti perkembangan dan kemajuan zaman, oleh karena itu sekolah-sekolah memerlukan guru. Guru bertugas mendidik anak didik agar mereka mendapat pendidikan dan pembinaan dari beberapa orang guru yang mempunyai kepribadian dan mental masing-masing. Setiap guru mempunyai pengaruh terhadap anak didik. Pengaruh tersebut ada yang terjadi melalui pendidikan dan pengajaran yang dilakukan dengan sengaja dan ada pula yang terjadi secara tidak sengaja, bahkan tidak disadari oleh guru, melalui sikap, gaya, dan macam-macam penampilan kepribadian guru (Zakia Drajat, 2005).

Guru adalah pendidik, yang menjadi tokoh, panutan dan identifikasi bagi para peserta didik, dan lingkungannya. Oleh karena itu, guru harus memiliki standar kualitas pribadi tertentu, yang mencakup tanggung jawab, wibawa, mandiri dan disiplin. Tanggung jawab guru di sini adalah mencerdaskan kehidupan anak didiknya. Tidak ada guru pun yang mengharapkan anak didiknya menjadi sampah. Untuk itu guru dengan penuh dedikasi dan loyalitas berusaha membimbing dan membina anak didik agar di masa mendatang menjadi orang yang berguna bagi nusa dan bangsa.

Guru memiliki pengaruh artinya keseluruhan tingkah laku yang dilakukan guru dalam melaksanakan tugasnya sebagai guru mempunyai peranan amat luas, baik di sekolah, keluarga, dan di dalam masyarakat. Di sekolah, guru bertugas sebagai perancang atau perencana, pengelola pengajaran dan pengelola hasil pembelajaran peserta didik, guru di sekolah ditentukan oleh kedudukannya sebagai orang dewasa, sebagai pengajar, dan yang paling utama adalah kedudukannya sebagai pengajar dan pendidik, yakni sebagai guru, ia harus menunjukkan perilaku yang layak (bisa dijadikan teladan oleh peserta didiknya) (Tohirin, Tanpa Tahun).

Tingkah laku atau moral guru pada umumnya merupakan penampilan dari kepribadiannya, misalnya dalam tindakannya, ucapan, cara bergaul, berpakaian, dalam menghadapi setiap persoalan atau masalah, baik yang ringan maupun yang berat. Guru yang perperilaku tidak baik akan merusak citranya sebagai guru yang pada gilirannya 
akan dapat merusak peserta didiknya yang dipercayakan kepadanya. Oleh sebab itu, apabila ada peserta didik yang berperilaku menyimpang, mungkin hal itu disebabkan oleh perilaku gurunya yang tidak memberi telada baik. Faktor terpenting bagi seorang guru adalah kepribadiannya, kepribadian itulah yang akan menentukan apakah ia menjadi pendidik dan Pembina yang baik bagi peserta didiknya atau malah sebaliknya.

Dalam menjalankan tugas sehari-hari, seringkali pengajar harus berhadapan dengan siswa-siswa yang prestasi akademisnya tidak sesuai dengan harapan pengajar. Bila hal ini terjadi dan ternyata kemampuan kognitif siswa cukup baik, pengajar cenderung untuk mengatakan bahwa siswa tidak bermotivasi dan menganggap hal ini sebagai kondisi yang menetap. Oleh karena itu para guru sangat menyadari pentingnya motivasi di dalam membimbing belajar murid. Dengan adanya motivasi, baik berupa pujian, hadiah maupun yang bersifat positif, siswa akan bersemangat dalam menjalankan tugasnya sebagai pelajar yaitu belajar agar dapat meraih prestasi yang lebih baik. Oleh karena guru, sangat besar pengaruhnya dalam memotivasi anak didiknya untuk mau belajar. Karena belajar yang efektif itu adalah belajar yang cukup untuk memperoleh motivasi dari guru yang memiliki kepribadian yang dinamik yang tercermin di dalam sikap dan minatnya sendiri yang diperoleh dari pengaruh-pengaruh yang luas dan berdasarkan pengalaman-pengalaman yang kaya (Slameto, 1995).

Dimyati dan Mudjiono mengatakan bahwa motivasi belajar penting bagi siswa dan guru. Bagi siswa motivasi belajar untuk menyadarkan kedudukan pada awal belajar, proses dan hasil akhir, menginformasikan tentang kekuatan usaha belajar, yang dibandingkan dengan teman sebaya. Sebagai ilustrasi, jika terbukti usaha belajar seorang siswa belum memadai guru, mengarahkan kegiatan belajar, membesarkan semangat belajar, menyadarkan siswa akan adanya perjalanan belajar. Manfaat bagi guru adalah membangkitkan, meningkatkan, memelihara semangat siswa untuk belajar sampai berhasil (Dimyati \& Mudjiono, 2002).

Penelitian terdahulu oleh Umi Saidatulrahmah yang berjudul "Pengaruh Persepsi Siswa tentang Metode Resitasi terhadap Motivasi Belajar PAI Siswa Kelas VIII SMP Negeri 16 Semarang Tahun Pelajaran 2007/2008”. Hasil penelitian Saidah menunjukkan, bahwa ada pengaruh yang signifikan antara pemberian resitasi (tugas) yang diberikan guru terhadap dorongan siswa untuk belajar. Hal ini dibuktikan dari analisis uji F yang diketahui nilainya sebesar 20,44 signifikan pada taraf signifikansi 5\% dan 1\% (Umi Saidatulrahman, 2004). Penelitian lainnya oleh Rohmat yang berjudul "Persepsi Siswa Tentang Kewibawaan Guru PAI dan Pengaruhnya Terhadap Motivasi Belajar Siswa di SDN Ngasinan Kecamatan Weleri Kabupaten Kendal Tahun 2003-2004”. Penelitian Rohmat ini lebih memfokuskan penelitiannya pada interpretasi siswa terhadap pembawaan seseorang untuk menguasai dan mempengaruhi sikap dan tingkah laku yang mengandung kepemimpinan dan penuh daya tarik yang mengandung kepemimpinan dan penuh daya tarik yang berkaitan dengan suatu kondisi psikologis yang mendorong 
seseorang untuk belajar demi mencapai tujuan pembelajaran di SDN Ngasinan Kecamatan Weleri Kabupaten Kendal (rohmat, 2004).

SMP N 3 Mattirosompe merupakan salah satu lembaga pendidikan, jika dilihat dari interaksi proses belajar mengajar, maka tanggung jawab guru sangat minim, khususnya guru biologi. Hal ini disebabkan karena guru biologi masih kurang memperhatikan dirinya sendiri, baik dalam hal tindakan, sifat, tutur kata, cara berpakaian dan lain-lain, sehingga mrngakibatkan peserta didiknya mengikuti dan berpengaruh buruk kepada keberhasilan mereka dalam proses pembelajaran.

\section{METODE PENELITIAN}

Jenis penelitian yang digunakan adalah deskriptif dengan pendekatan kuantitatif. Penelitian deskriptif adalah penelitian yang dimaksudkan untuk mengumpulkan informasi-informasi mengenai status gejala yang ada, yaitu keadaan gejala menurut apa adanya pada saat penelitian dilakukan. Sedangkan penelitian kuantitatif adalah suatu proses pengumpulan data berupa angka sebagai alat penemuan keterangan mengenai apa yang ingin kita ketahui (Arikunto. S, 1998). Yang menjadi variabel dalam penelitian ini adalah: Variabel bebas (variabel X) adalah pengaruh kepribadian guru biologi, dengan indikator: cara berbuat, sikap, minat, dan temperamen emosional. Variabel terikat (variabel Y) adalah motivasi belajar peserta didik, dengan indikator: perasaan senang belajar, semangat belajar, dan niat yang kuat untuk belajar

Adapun beberapa teknik yang digunakan dalam penelitian ini antara lain:

1. Observasi atau pengamatan: Yaitu teknik pengumpulan data yang dilakukan dengan cara langsng melihat objek atau lokasi penelitian tentang keadaan lapangan dengan gejala-gejala yang diselidiki.

2. Angket: Angket merupakan metode pengumpulan data dengan cara menyebar kuisioner (daftar pertanyaan). Kuisioner dilanjutkan kepada responden dalam bentuk angket.

3. Dokumentasi: Dokumentasi adalah ditujukan untuk memperoleh data langsung dari tempat penelitian, meliputi buku-buku yang relevan, peraturan-peraturan, laporan kegiatan, foto-foto, film dokumenter, data yang relevan penelitian.

Teknik ini bertujuan setelah data terkumpul dari hasil pengumpulan data, perlu segera dianalisis oleh peneliti. Jadi ketika data sudah dikumpulkan maka teknik yang digunakan dalam menganalisis data ini adalah sebagai berikut:

1. Teknik analisis distribusi frekuensi

Yaitu untuk menghitung hasil angket tentang pengaruh kepribadian guru biologi terhadap motivasi belajar peserta didik di SMP N 3 Mattirosompe dengan menggunakan rumus sebagai berikut (Anas Sujiono, 1987):

$$
\mathrm{P}=\frac{F}{N} \mathrm{X} 100 \%
$$

Keterangan: $\quad \mathrm{P}=$ Angka persenan 


$$
\begin{aligned}
\mathrm{F} & =\text { Frekuensi yang sedang dicari persentasenya } \\
\mathrm{N} & =\text { Number of Cases (jumlah frekuensi/banyaknya individu) }
\end{aligned}
$$

2. Teknik Analisis Product Moment

Untuk menghitung apakah terdapar pengaruh kepribadian guru biologi terhadap motivasi belajar peserta didik di SMP N 3 Mattirosompe dengan menggunakan rumus sebagai berikut:

Keterangan:

$$
r_{x y}=\frac{N \sum X Y-\left(\sum X\right)\left(\sum Y\right)}{\sqrt{\left[N \sum X^{2}-\left(\sum X\right)^{2}\right]\left[N \sum Y^{2}-\left(\sum Y\right)^{2}\right]}}
$$

$\mathrm{r}_{\mathrm{xy}}=$ Angka indeks korelasi "r" Product moment

$\sum X=$ Jumlah seluruh skor $\mathrm{X}$

$\sum \mathrm{Y}=$ Jumlah seluruh skor $\mathrm{Y}$

$\sum X Y=$ Jumlah hasil perkalian antara skor $\mathrm{X}$ dan skor $\mathrm{Y}$

$\mathrm{N}=$ Number of Cases (jumlah frekuensi/banyaknya individu).

3. Teknik Analisis koofisien determinasi

Kemudian untuk menguji besar pengaruh kepribadian guru biologi terhadap motivasi belajar peserta didik di SMP N 3 Mattirosompe menggunakan rumus koofisien determinasi yaitu:

$\mathrm{KD}=\mathrm{r}^{2} \times 100 \%$

Keterangan: $\mathrm{KD}=$ Koofisien determinasi

$\mathrm{r}^{2} \quad=$ Nilai korelasi

\section{HASIL DAN PEMBAHASAN}

\section{Kepribadian Guru Biologi}

Pada prinsipnya guru adalah pendidik profesional dengan tugas utama mendidik, mengajar, membimbing, mengarahkan, melatih, menilai, dan mengevaluasi peserta didik pada pendidikan menengah. Untuk menjadi guru pendidikan biologi yang berkelayakan dituntut persyaratan formal juga harus mempunyai kepribadian dan perilaku yang baik. Sebab tugas guru pendidikan biologi adalah memberikan bantuan dan contoh kepada kepada peserta didik melalui tindakan dan perilaku, oleh sebab itu seorang sosok guru pendidikan biologi yang merupakan panutan akan ditiru harus memiliki perilaku dan dedikasi yang tinggi dan terpuji, maka di sini pula seorang guru pendidikan biologi tidak hanya profesional tetapi juga harus profesional dalam menjalankan tugasnya. Karena seorang guru biologi akan dihadapkan dengan berbagai keadaan peserta didik dengan latar belakang kehidupan sosial, psikologi dan kepribadian serta perilaku dan karakteristik yang beraneka ragam.

Untuk mengumpulkan data tentang kepribadian guru biologi, peneliti menyebarkan angket kepada 30 orang peserta didik sebagai responden dalam penelitian yang peneliti laksanakan yang dilakukan pada kelas VIII, yaitu kelas VIII A. $_{\text {. }}$ 
Angket yang disebarkan kepada 30 orang sebanyak 20 item yang terdiri dari pertanyaan atau item angket diberi skor untuk jawaban $\mathrm{a}=4, \mathrm{~b}=3, \mathrm{c}=2, \mathrm{~d}=1$, dan $\mathrm{e}=0$, untuk pertanyaan positif. Dalam hal ini pengaruh kepribadian guru biologi, dilakukan dalam bentuk angket. Angket yang disebarkan pada 30 peserta didik sebanyak 35 pertanyaan, yang masing-masing terdiri dari 20 pertanyaan untuk variabel $\mathrm{X}$ (pengaruh kepribadian guru biologi) dan 15 untuk variabel Y (motivasi belajar peserta didik) di SMPN 3 Mattirosompe.

Dari perhitungan analisis korelasi, diketahui bahwa $\mathrm{N}=30$ dengan teknik analisis data menggunakan rumus product moment dengan hasil perhitungan adalah 0,48 . Dengan demikian hasil ini apabila di cocokkan pada taraf signifikan $5 \%$ dimana $r_{\text {hitung }} 0,48>r_{\text {tabel }}(0,48>0,374)$. Sehingga dapat diketahui bahwa kepribadian guru biologi terhadap motivasi belajar peserta didik di kelas VIII SMP Negeri 3 Mattirosompe dan terdapat pengaruh signifikan korelasi yang sedang atau cukup. Dari uraian analisis kepribadian guru biologi terhadap motivasi belajar peserta didik memberikan gambaran bahwa hubungan kepribadian guru yang terkait dengan motivasi belajar peserta didik ternyata terlaksana dengan sistematis dan terorganisir. Namun perlu ditekankan sekali lagi bahwa program yang tersusun secara sistematis serta upaya yang digalakan secara maksimal, bukan berarti bahwa semua itu yang dapat dijadikan tolak ukur keberhasilan dalam bentuk pencapaian hasil belajar yang tinggi bagi peserta didik.

\section{Nilai Determinasi}

Uji hipotesis yang dilakukan menunjukkan bahwa Hipotesis $\mathrm{H}_{\mathrm{a}}$, terdapat pengaruh kepribadian guru biologi terhadap motivasi belajar peserta didik di SMP N 3 Mattirosompe pada taraf signifikan 5\% dan terdapat korelasi yang sedang atau cukup signifikan antara variabel X dan variabel Y. Selanjutnya untuk mengetahui berapa besar pengaruh kepribadian guru biologi (variabel $\mathrm{X}$ ) terhadap motivasi belajar peserta didik (variabel Y) di SMP Negeri 3 Mattirosompe, digunakan rumus koefesien determinasi yaitu 23\%. Dalam hal ini, motivasi belajar juga dipengaruhi oleh kondisi peserta didik (kondisi psikis dan jasmani), kondisi lingkungan peserta didik, dan unsur-unsur dinamis dalam belajar dan pembelajaran.

Berdasarkan hasil penelitian deskriptif kuantitatif yang dilakukan sesudah perbedaan-perbedaan yang terjadi pada variabel bebas, ternyata terdapat pengaruh kepribadian guru biologi (variabel X) terhadap motivasi belajar peserta didik (variabel Y) di SMP Negeri 3 Mattirosompe yaitu adalah 0,48, kemudian dari 30 peserta didik yang diambil secara sampling kelas yang peneliti lakukan dengan penjabaran rata-rata dengan variabel pengaruh kepribadian guru biologi (variabel $\mathrm{X}$ ) maka peserta didik yang memilih jawaban selalu sebesar 59,3\%, untuk jawaban sering sebesar 23,3\%, untuk jawaban kadang-kadang sebesar 9,2\%, untuk jawaban tidak sebesar 6,1\%. Sedangkan untuk jawaban tidak sama sekali adalah $2,1 \%$.

BIOLOGI SEL (VOL 6 NO 1 EDISI JAN-JUN 2017 ISSN 2252-858X/E-ISSN 2541-1225) PAGE 99 
Kemudian untuk mengetahui motivasi belajar peserta didik (variabel Y) dijabarkan ke dalam instrumen angket yaitu berupa penjabaran rata-rata maka peserta didik yang memilih jawaban selalu sebesar $61,85 \%$ untuk jawaban sering sebesar $21,63 \%$. untuk jawaban kadang-kadang $8,52 \%$, untuk jawaban tidak 3,06\%, sedangkan untuk jawaban tidak sama sekali adalah 3,24\%. Dari hasil penelitian yang diperoleh dari perhitungan dengan menggunakan rumus korelasi product moment di atas, diketahui bahwa untuk koefisien korelasi sebesar 0,48 dan setelah dikonsultasikan dengan tabel interpretasi, ternyata angka "r" $(0,374)$, interpretasi yang menunjukkan bahwa terdapat pengaruh kepribadian guru biologi (variabel $\mathrm{X}$ ) terhadap motivasi belajar peserta didik (variabel Y) di SMP Negeri 3 Mattirosompe, terdapat korelasi yang sedang atau cukup signifikan.

Sehingga hasil perhitungan antara variabel $X$ dan variabel $Y$ sebesar $r x y=0,48$. Dan pengujian hipotesis dengan derajat bebas $(\mathrm{Db})=30$, ternyata $\mathrm{r}_{\text {hitung }}>\mathrm{r}_{\text {tabel }}$ pada taraf signifikan 5\% sebesar 0,374, berarti 0,48>0,374. Dengan demikian hipotesis Hi diterima dan Ho ditolak. Kemudian diperoleh koefesien determinasi dengan besar pengaruh $\left(\mathrm{r}^{2}\right)$ adalah 23\%. Maka besar pengaruh kepribadian guru biologi (variabel X) terhadap motivasi belajar peserta didik (variabel Y) di SMP Negeri 3 Mattirosompe adalah 23\%. Tingginya nilai korelasi yang diperoleh dari hasil penelitian disebabkan karena beberapa faktor, yakni (1) guru mata pelajaran biologi sudah menunjukkan kepribadian yang baik dalam proses belajar mengajar, (2) peserta didik memiliki motivasi yang tinggi untuk belajar, (3) kondisi lingkungan yang mendukung sehingga proses belajar mengajar berlangsung optimal.

Karena menjadi guru biologi yang berkelayakan dituntut persyaratan formal juga harus mempunyai kepribadian dan perilaku yang baik. Sebab tugas guru biologi adalah memberikan bantuan dan contoh kepada kepada peserta didik melalui tindakan dan perilaku, oleh sebab itu seorang sosok guru biologi yang merupakan panutan akan ditiru harus memiliki perilaku dan dedikasi yang tinggi dan terpuji, maka di sini pula seorang guru biologi tidak hanya profesional tetapi juga harus profesional dalam menjalankan tugasnya. Karena seorang guru biologi akan diperhadapkan dengan berbagai keadaan peserta didik dengan latar belakang kehidupan sosial, psikologi dan kepribadian serta perilaku dan karakteristik yang beraneka ragam.

Dalam pembelajaran motivasi belajar peserta didik tidak hanya dipengaruhi oleh kepribadian guru, tetapi juga dipengaruhi oleh tiga faktor, yaitu faktor internal, eksternal, dan pendekatan belajar. Faktor internal (faktor dari dalam diri siswa), yakni keadaan jasmani dan rohani siswa meliputi aspek fisiologis (jasmaniah) dan psikologis (rohaniah, seperti tingkat kecerdasan, inteligensi siswa, sikap, bakat, minat, dan motivasi). Sedangkan faktor eksternal (faktor dari luar diri siswa), yakni kondisi lingkungan di sekitar siswa, baik sosial, seperti para guru, tenaga kependidikan, dan teman-teman sekelas yang mempengaruhi semangat belajar siswa dan nonsosial, seperti gedung 
sekolah dan letaknya, rumah keluarga dan letaknya, alat belajar, keadaan cuaca dan waktu belajar yang digunakan siswa. Kemudian faktor pendekatan belajar (approach to learning), yakni jenis upaya belajar siswa yang meliputi strategi dan metode yang digunakan siswa untuk melakukan kegiatan mempelajari materi-materi pelajaran (Muhibbin Syah, 2014).

\section{KESIMPULAN}

1. Terdapat pengaruh kepribadian guru biologi (variabel $\mathrm{X}$ ) terhadap motivasi belajar peserta didik (variabel Y) di SMP Negeri 3 Mattirosompe adalah 0,48. Ini membuktikan bahwa terdapat korelasi yang sedang atau cukup signifikan antara variabel $\mathrm{X}$ dan variabel $\mathrm{Y}$.

2. Besar pengaruh kepribadian guru biologi (variabel $\mathrm{X}$ ) terhadap motivasi belajar peserta didik (variabel Y) di SMP Negeri 3 Mattirosompe adalah 23\%.

\section{SARAN}

1. Diharapkan kepada lembaga pendidikan dalam hal ini sekolah, dalam menyusun pembelajaran dan langkah-langkah teknik harus merujuk kepada kebutuhan sekolah dan evaluasi program untuk menelaah atau menganalisis program yang telah dan sedang berjalan serta melibatkan pihak terkait (stakeholders) seperti kepala sekolah, para guru, tenaga administrasi, orang tua, dan komite sekolah serta dilaksanakan di awal tahun ajaran atau setelah program semester berakhir, selanjutnya dilakukan evaluasi.

2. Dengan adanya strategi pembelajaran di sekolah diharapkan peserta didik memiliki keinginan yang kuat dan mampu keluar dari masalah-masalah belajar, agar dapat meraih hasil belajar yang lebih baik dari hari-hari sebelumnya.

3. Diharapkan kepada kepala sekolah, staf dewan guru, orang tua, komite sekolah dan masyarakat agar lebih dapat membantu dan memperhatikan proses beajar mengajar untuk meningkatkan pelayanan terutama dalam masalah belajar dan etika atau aturan di masyarakat.

4. Diharapkan kepada mahapeserta didik dalam menyelesaikan penelitian selanjutnya, dalam sebuah penelitian agar lebih paham tentang fenomena dari masalah yang diteliti sehingga mampu dipertanggung jawabkan untuk menjadi seorang sarjana.

\section{DAFTAR PUSTAKA}

Achmadi, Abu dan Widodo Supriyono. 2004. Psikologi Belajar. Jakarta: Rineka Cipta. Ahmadi, Abu Dan Nur Ubhiyati. 1991. Ilmu Pendidikan. Jakarta: PT Rineka Cipta. AM, Sardiman. 1992. Interaksi dan Motivasi Belajar Mengajar. Jakarta: Rajawali. Arikunto, Suharmi. 1998. Manajemen Penelitian. Jakarta: Rineka Cipta. B. Sobur, Alex. 2003. Psikologi Umum. Bandung: CV. Pustaka Setia. 
Daien Indrakusuma, Amir. 1978. Pengantar Ilmu Pendidikan. Surabaya: Usaha Nasional. Daradjat, Zakiah. 2005. Kepribadian Guru. Jakarta: Bulan Bintang.

Departemen Agama Direktorat Jendral Kelembagaan Agama Islam. 2002. Wawasan Tugas Guru dan Tenaga Kependidikan. Bandung: PT. Rosdakarya.

Dimyati dan Mudjiono. 2009. Belajar dan Pembelajaran. Jakarta: Asdi Mahasatya.

Djamarah, Syaiful Bahri. 1997. Guru dan Anak Didik Dalam Interaksi Edukatif. Jakarta: Rineka Cipta.

H. Bower, Gordon dan Ernest R. Hilgard. 1981. Theories of Learning. London: Prentice Hall International.

Hamalik, Oemar. 2002. Psikologi Belajar dan Mengajar. Bandung: Sinar Baru Algensindo.

Hanikah. Hubungan Kepribadian Guru, dari http://hanikah.blogspot.com/hubungankepribadian-guru.html, diakses 30 Desember 2016

HM, Ahmad Rohani dan Abu Ahmadi. 1990. Pengelolaan Pengajaran. Jakarta: Rineka Cipta.

Jalaludin. 2005. Psikologi Agama. Jakarta: Raja Grafindo Persada.

Kartono, Kartini. 1979. Teori Kepribadian. Bandung: Alumni.

Khozizah, Siti. 2008. Pengaruh Persepsi Siswa Tentang Kepribadian Guru PAI terhadap Motivasi Belajar PAI Siswa Di Mts Mujahidin Desa Bageng Kecamatan Gembong Kabupaten Pati, Skripsi. Semarang: IAIN Walisongo.

Mulyasa. 2009. Menjadi Guru Professional Menciptakan Pembelajaran Kreatif Dan Menyenangkan. Jakarta: PT. Remaja Rosdakarya.

Mustaqim dan Abdul Wahib. 2003. Psikologi Pendidikan. Jakarta: Rineka Cipta.

P. Miller, John. 2002. Cerdas di Kelas; Sekolah Kepribadian, terjemahan Abdul Munir Mulkhan. Yogyakarta: Kreasi Wacana.

Renyaan, Zakia H. 2015. Hubungan Kompetensi Kepribadian Guru Dengan Motivasi Belajar Peserta Didik Pada Mata Pelajaran Biologi di Kelas VIII SMP Al- Wathan Ambon. Skripsi. IAIN Ambon: FITIK.

Rohmat. 2004. Persepsi Siswa Tentang Kewibawaan Guru PAI dan Pengaruhnya Terhadap Motivasi Belajar Siswa di SDN Ngasinan Kecamatan Weleri Kabupaten Kendal. Semarang: Fakultas Tarbiyah.

Sabri, Alisuf. 1996. Psikologi Pendidikan. Jakarta: Pedoman Ilmu Jaya.

Saidatulrahmah, Umi. 2004. Pengaruh Persepsi Siswa tentang Metode Resitasi terhadap Motivasi Belajar PAI Siswa Kelas VIII SMP Negeri 16 Semarang Tahun Pelajaran 2007/2008. Semarang: Fakultas Tarbiyah.

Saondi, Ondi \& Suherman Aris. 2010. Etika Profesi Keguruan. Bandung: PT Refika Aditama,

Slameto. 1995. Belajar dan Faktor-faklor yang Mempengaruhinya. Jakarta: Rineka Cipta.

BIOLOGI SEL (YOL 6 NO 1 EDISI JAN-JUN 2017 ISSN 2252-858X/E-ISSN 2541-1225)PAGE 102 
Soemanto, Wasty. 1998. Psikologi Pendidikan. Jakarta: Rineka Cipta.

Sujiono, Anas. 1987. Pengantar Statistik Pendidikan. Jakarta: Rajagrafindo Persada.

Suyanto, Djihad. 2013. Calon Guru Dan Guru Professional. Yogyakarta: Multi Pressindo.

Syah, Muhibbin. 2014. Psikologi Pendidikan Dengan Pendekatan Baru. Bandung: Remaja Rosdakarya

Tohirin. 2010. Psikologi Pembelajaran Pendidikan Agama Islam. Jakarta: PT. Raja Grafindo Persada.

Undang-undang RI No. 14 Tahun 2005 tentang Guru dan Dosen. 2006.

Utsman Najati. 1997. M. al-Qur'an dan Ilmu Jiwa, terj. Ahmad Rofi' 'Usman. Bandung: Pustaka.

Wael, Jumiati. 2012. Pengaruh Kompetensi Kepribadian Guru Biologi terhadap Minat Belajar Siswa di SMPN 8 Amahai Satu Atap Dusun Ampera Desa Tamilow Kecamatan Amahai Kabupaten Maluku Tengah. Skripsi. IAIN Ambon: FITK. 